\title{
ボイドの等価回路とボイド放電の 経時変化との対応
}

$\begin{array}{lllll}\text { 武蔵工業大学 } & \text { 伊 } & \text { 藤 } & \text { 泰 郎 } \\ \text { 武蔵工業大学 } & \text { 堺 } & \text { 孝 夫 } \\ \text { 武蔵工業大学 } & \text { 鳥 山 四 男 }\end{array}$

\section{1. まえがき}

絶縁材料, 特に高電圧機器やケーブルに用いられて いる高分子絶緣材料の劣化に関する研究が, 最近盛ん に行なわれるようになっている。その中で李酎部分放 電劣化現象は重要であり，乥の試験法としてす，集中 法(1)，IEC 法(2)などが取り上げられ，筹命や材料の物 理化学的変化を含めた劣化機構などの基礎的な性質が

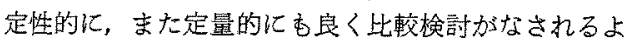
うになってきている。

一方，実用機器絶縁や絶縁材料口部分放電炙化は， これらに含されるボイドから発生するととが大部分で あることから，ボイドを含を試料の多化試験が古くか ら行なわれたことはあっても，

(1) ボイド中で放電発生場所が移動する(4)

(2) そのため放電が聞久的になり ${ }^{(3)}$

(3) ボイド中で安定に放電定発生させるこよが困 難である(3)

などのボイド放電ダ化特有の放笔現象岂伴うために， 絶縞材料の劣化比較試験や，寿命之電気的諸量の関連 绕省ボイド試料について求めることは困難とされてき た。そのため劣化現象を解析するためには，ボイド放 電試験を最す簡単化した模擬試験法として，集中法や IEC 法に依存してきたのが害状である。これらの簡

A New Equivalent Circuit to Explane the Time Dependence of the Artificial Void for the Corona Resistance Measurement. By T. ITO, Member, T. SAKAI, Menber \& Y. TORIYAMA, Honorary member (Department of Electrical Engineering, Musashi Institute of Technology)

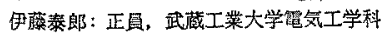

畦 慗失: 正員, 武盛工莱大学電気工学科

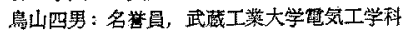

単化された模擬試験法によって，劣化量上電気的諸畽 の関係が定量的にす明らかにされてきている。てれに 伴い実用的見地加らもボイド放電特有な，前述(1) （3）項に示した現象を解明することが，実用に即した 絶縁劣化嘰構安明らかにする手が加り上考えられる。

本研究は，機器絶縁中のボイド放電劣化㙨構を明ら 加にする見地加ら，絶縁物中にボイド含す試料を， 従来から考えられてきたコンデンサのみによる等価回 路(5)にボイド特有なボイド内壁面提抗を考慮した模擬 等価回路を提案した。印加電死が放電発生可能なギャ ップに分圧される電生の大きさから，ボイド放電特有 の現象を提案した等価回路と対照させて説明するこよ ができるようになった。また，従来考克られていなか ったボイドに卵加される電界と直角方向にも放電が発 生する可能性があることを示すととができ，あわせて 部分放電の大きさに関する分布の時間推移を，放電少 化に伴うボイド内気体成分变化之ボイド内壁面抵抗の 変化加ら説明できるようになった。

\section{2. ボイド含有絶縁物の等価回路}

〈2.1〉従来の等価回路絶縁物中存在するボ イドギャップに加わる電王が，そのギャップの放電電 圧に達するとボイド中の空気の笔離が票輤的に起こ り，その結果，発生した電子やイオンが絶縁物表面に たい積する。このたい皘電荷の逆電界によって，ギャ ップ電界が放電消㓕霄界，あるいはそれ以下に低下寸 ることによって電離が停止し，I個のパルス的放電が 停止すると考えられている(3)。䋓縁物と導体界面の間 などで発生する放電の場合にもこの党え方が適用さ れ，現在でもこの機構をもとにした研究が各方面で行

昭 $50-8$ 


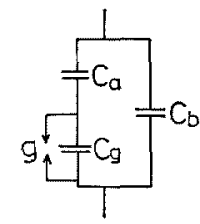

$C_{a}$ : 故電ギャップに直列な容盟

$C_{b}:$ 健全䍃緑層の静電容最

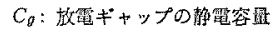

$a:$ 放電ギャップ

第 1 図 従来のボイドの等価回路

Fig. 1. A typical simplified equivalent circuit for a void in insulating materials.

なわれてきている(6)

定常的に放電が絽り返し発生している状態では，従 来からボイドを含す絶縁物試料の等価回路として第 1 四の回路が提案されている 応用され，゙゙ャップの放電によってギャップ電生 $V_{\text {。 }}$ が $\Delta V$ だけ低下するとして测定される見かけの放 電量 $Q \approx \Delta V \cdot C_{b}$ ○大きさ之，放電エネルギー $W$ $\approx Q \cdot V_{s} / 2\left(V_{s}:\right.$ ギャップの放電電王) の大きさが絶 緣材料の耐放電性試験法における出化量と良い対応を 示すため，等価回路として第 1 困の回路化よる取り扱 いが多く行なわれてきている(7)。

一方，容量のみによって構成された第 1 因のような 等洒回路は，放電がボイド中で繰り返し発生しても， 放電にさらされた誘電体の表面抵挖，体積抵抗を無限 大とみなせるような理想的誘電体の場合である。しか し，ここで取上げる高分子絶縁物中にボイドを含む試 料では，放電によってその少化面の表面抵抗が減少す

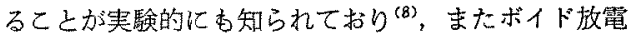
特有の放電の不安定性があたらされることも報告され

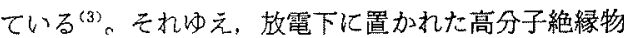
中のボイドを等価的に示すために，ボイド壁面抵抗を 導入することが提案された ${ }^{(9)}$ 。その結果，等価回路中 の壁面抵抗を通して放電電荷が再配分され，放電発生 数や放電エネルギーが変化するととが定性的に示され た。また同様に壁面抵抗を考慮した簡単な等価回路か ら，試料に加えられる電源周波数やボイド壁面抵抗の 翂化化よって，加速試験の周波数限界や放電点の転移 を示唆すること屯行なわれるようになってきている。

琴在までにいくつかの等価回路が提案されている が，これらでは，(a)ボイド中の放電点が移動する，

(b)放電の大きさが時間的に変化する，などの実験事 夹を結びつけるには至らず，次に示す等俩回路を提案 する。

〈2.2〉 ボイド含有試料の等価回路表示 ボイド を含む絶縁物試料を等価回路で示す場合には，ボイド

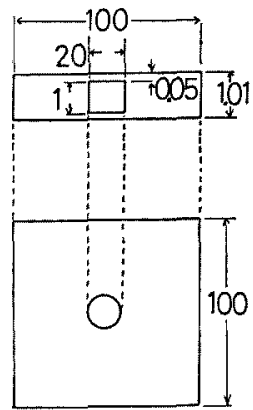

第 2 図試料形状

Fig. 2. Configuration of test specimen. 各部の容量や抵抗值を計算または実測によって各素子 に置換するので，ボイドの形状や大きさなどはあまり 問題とはしない。ここでは回路による解析を夷験的に 検討するため，

（1）模擬試験をする場合に同一条件のボイドを作 成しやすいとと

（2）等価回路表示に用いる素子の值を簡単に計算 によって求められる

(3) ボイド内の放電点の移動を確琶できること などの理由のため，第 2 図に示した平板状絶縁物中に 存在する，比較的大きな円柱状ボイドを仮定しだ。

このようなボイドを等侕回路表示するためには, 理 想誘電体として提案されている第 1 図の回路構成に， ボイド放電によって表わされる顕著な電気的特性とし て，ボィド内上下の表面抵抗およびボイド端壁面抵抗 を導入し，更にこの部分の放電電荷蓄積容量を含めた 回路を構成した。本来，ボイド試料を等侕回路で模擬 するためには分布定数回路によって示したほうが異赛 に近いが，取り扱いを容易にするために集中定数で考 えると第 3 図の上うに示すととができる。ここで，因 中に示した各素子および記号は次の意味をむたせた。

$C_{1}$ : 印加電圧に対しボイド部分と直列に入る上部の 誘電体の静電签量。

$C_{1^{\prime}}$ : 前の $C_{1}$ 之同様下部の静電容量で, ボイドが上 下対称形であればC、等しい。

$C_{2}:$ ボイド部分の静電容量。

$C_{3}$ : ボイド上下面に沿って起こる放電の電荷を蓄積 する容量。

$C_{4}$ : 次の $C_{5}$ と直列に入る上部誘電体の容量。

$C_{4}{ }^{\prime}: C_{4}$ と同様下部の容量で，上下対称ボイドであ ればC $C_{4}$ に同し。

$C_{5}$ : ボイド端周辺で起こる放電の電荷を落皘してい る容量。

$C_{6}$ : 導体間（実験采では上下電極間）のボイド部分 

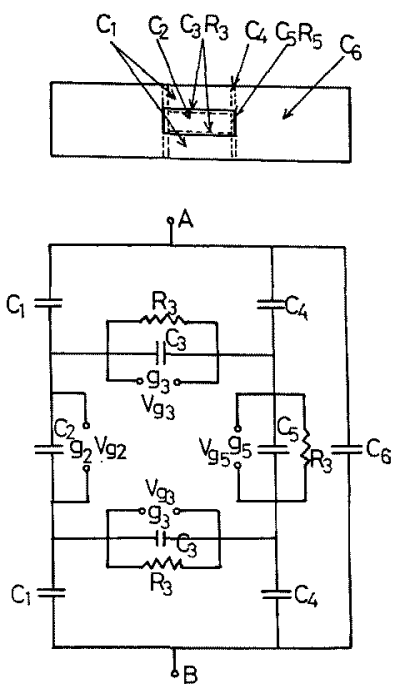

第 3 図 新しい等価圆路

Fig. 3. A proposed new equivalent circuit for a cavity in insulating materials.

以外の領域の容量。

$R_{3}, R_{5}: C_{3}$ および $C_{5}$ と並列に入る抵抗で，ボイド 上下沿面およびボイド端周辺の壁面抵抗（以下，文中 では各々の抵抗檤を $R_{3}, R_{5}$ の記号で示す)。

$V_{v 2}, V_{s 3}, V_{\theta 5}$ ：誘電体に電圧加印加されたとき，そ の電恠が各放電発生可能なギャップ $g_{2}, g_{3}, g_{5}$ に分王さ れる電圧（以下，文中では各分圧電王をこの記号で示 す)。

ここで示した等洒回路は，涏来から考えられてきた 等洒回路に坟して，ボイド端および上下沿面に沿う放 電の放電電荷の蓄皘容眰 $\left(C_{3}, C_{5}\right)$ およびこれに亚列に 入る表面抵抗 $\left(R_{3}, R_{5}\right)$ を渞入し，ボイドが誘電体内 に存在するような回路構成とした点に特徴をもってい る。なお，g3,g5 では

（1） g2で発生した放電によって，ボイド上下面に 不均一に電荷が蓄積され，この蓄皘電荷によって面に 沿う力向に不均一電界を生ずることおよび

（2）上下面の㸓化が不均一で表面抵抗の低下が不 均一となるたか，印加電界が局部的に高く分生される ととがあれ代放電が発生するし，g5 では単なる沿面放 電香発生する

と考えられる。これらの原因により発生する放電の電 荷を篦皘する容量を $C_{3}$ および $C_{5}$ とした。従って， $C_{3}, C_{5}$ は各々沿面放電を発生する点の間げきの容量に 対応する。

$\langle 2 \cdot 3\rangle$ 放電ギャップ分圧電圧の計算 等価回路
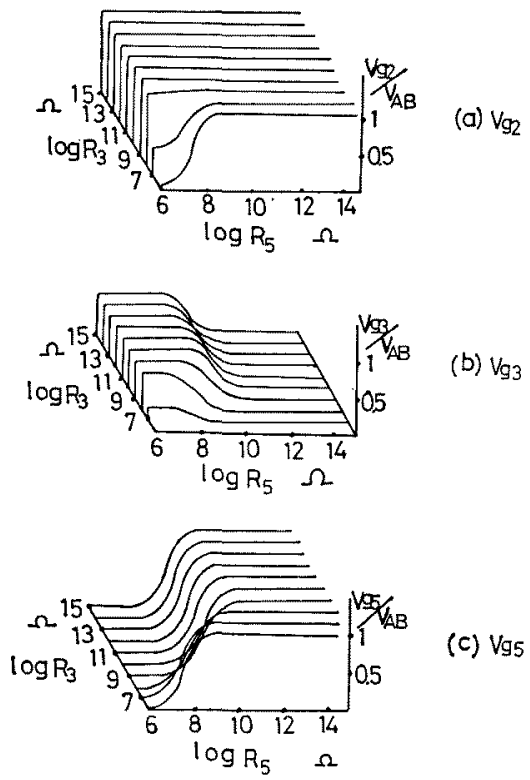

第 4 図 备放電部 0 分压電王特性

Fig. 4. The devided potential differences on three parts of the cavity.

第 1 表

Table 1.

\begin{tabular}{c|c}
\hline$C_{1}$ & 128. \\
\hline$C_{2}$ & 28. \\
\hline$C_{3}$ & 0.00028 \\
\hline$C_{4}$ & 1.28 \\
\hline$C_{5}$ & 0.028 \\
\hline$C_{8}$ & 46.5 \\
\hline
\end{tabular}

第 3 図の $A, B$ 点の間に交流電圧 $V$ を畞加したとき, $g_{2}, g_{3}, g_{5}$ に各インピーダンスによって分生される電生 $V_{q 2}, V_{q 3}, V_{q 5}$ を求める。ボイド上下面抵抗 $\left(R_{3}\right)$ およ びボイド端壁面抵抗 $\left(R_{5}\right)$ に伴う各分王電圧の計算結 果を第 4 図（a）（c）に示す。盯加電圧の周波数を $50 \mathrm{~Hz}$ とし, 各分圧電在を印加電圧との比で規格化し て示した。またここではボイドが刘称形であるとC $=C_{1^{\prime}}, C_{4}=C_{4^{\prime}}{ }^{\prime}$ である。各素子の值は第 2 図に示した 形状㧍よび大きさで，絶縁物はポリエチレンしして求 め，その值を第 1 表に示した。

等価回路中に示した $C_{3}, C_{5}$ の签量は放電電荷を蓄 積している素子として導入したが， $C_{3}, C_{5}$ の徝の選定 は次の上うに行なった。 $C_{9}, C_{5}$ の値は放電電荷を蓄わ えるに十分の大きさで，各部に分圧される電生には依 存しない範囲に定める必要がある。金属対誘電体間ギ

昭 $50-8$ 
ヤップまたは諒電体対誘電体間ギャップにおいて，個 々のパルス性放電化あずかる放電面積や位置は放電ギ ヤップ長や印加電压によって異なる。しかし，本解析で 考元ている商用周波数の正弦波では，印加電圧の上开 速度 $d V / d t$ 方放電形成時間( $\mathrm{ns}$ 程度) 上り㜊く, 放電 ギャップ $1 \mathrm{~mm}$ 位の場合には放電面積が $1 \mathrm{~mm}^{2}$ 程度で あるとされている(3) 従って，C5 はこの闻皘よりも 裁分大きく $3 \mathrm{~mm}^{2}$ として計算した。また 值の $1 / 100$ 之仮定したが，第1 表からわかるように $C_{3}, C_{5}$ の大きさは他の容量素子の值に比べて小さな值 を示しているため，分圧電圧には大きな変化としては 影響していない。このことは $C_{3}, C_{5}$ を各々 $10^{-13} \sim$ $10^{-18} \mathrm{~F}$ の範田で変化してむ，ま大印加電王の周波数 を $5 \mathrm{kHz}$ まで変化しても, 分王電王特性はほ第 4 困と同様で，その愦差は 1 2\% に止まる。

第 4 图汇示された計算結果は，ボイドで放電が起こ らず，更にボイド䉓圧が上昇して行くとして，放電発 生可能なギャップ $g_{2}, g_{3}, g_{5}$ 亿分圧される電圧を示して いる。分王電生が放電開始電圧以下では放電が発生女 ず，放電開始電仕を超えると放電が起こり，更に分圧 電圧が上昇するにつれ放笔発生繰り返し数が增加する 之考える。第 4 図化示される各分压電王特性吕ら示唆 されるのは次の事項である。

(a) ボイド中 $\left(g_{2}\right)$ に分圧さ机る電圧 $V_{s^{2}}$ は， $R_{3}$, $R_{5}$ がこむに $10^{8} \Omega$ 以上では $R_{3}, R_{5}$ の変化に依存し ないが，それ以下になると $V_{92}$ 功急激に低下し，ボ イド部分には電圧が加わらず，放電が停止する可能性 を示す。従って，ボイド中の放電が発生したり，停止 して間欠的となる現象は， $R_{3}, R_{5}$ の抵抗值吕 $10^{8} \Omega$ 以 下に低下した領域であろう。

(b) ボイド上下表面（g3）に分圧される電圧 $V_{a 3}$ が高い領域では，印加電界と直角方向の放電が発生す ることを意味しており，この点について考應された解 析は今までなされていない。 $V_{03}$ は $R_{5}$ が $10^{10} \Omega$ 以 下海少した場合に增加するが， $R_{3}$ 加 $10^{10} \Omega$ 以下儿 まで滅少する状態では $V_{0} 3$ は低下し，放電発生の可 能性が次第に減少する。

(c) ボイド端（g5）に分圧される電压 $V_{0}$ s は，前 項 (b) 亿示した特性と逆で，R5の值が $10^{9} \sim 10^{10} \Omega$ 以 上で $V_{\theta 5}$ が上昇するが，それ以下の $R_{5}$ の值では放 電発生の可能性がなくなる。

\section{3. ボイド放電孚化実験の結果}

ボイド放電劣化試験を行なう場合，ボイドが密開さ れているか開放されているかによって告化進展過程が 幾分異なり，特に開放されている場合には外部ふ九い
気の影響を受ける(10)ので，ててでは完全密閉された ボイドをポリエチレンフィルムのはり合せによって作 り，それに電圧を加えて放電状意の観察学行なった。 実踰結果中，放電劣化化伴いボイド内の酸素の減少， $\mathrm{CO}_{2}$ や $\mathrm{H}_{2}$ などの発生が見られ，ボイド内気圧が変 化することはボイド放䉓劣化特有の現皇であることを 前報(11)において述べた。なお，こてで行なった実験 では交流 $50 \mathrm{~Hz}$ 使用したが, 試料, 電極系, 方法 などについては前報(4) と同㥞であるので省略する。京 た，以下に洛々代表的な一つの测定結黑のみ示した が，ボイドの大きさや印加電圧には依存世ず，定性的 にはほほ同様な傾向を示す。

〈3.1〉放電分布の経時変化 集中法や IEC 法な どにおいては電王印加開始時から放電分布の経時㚆化 が密閉されたボイド放電礼ど頙著に示されないのに対 して，ボイド放電ではその列第5图に示す上うに急 激な時間推移を示す。すな和ち，電圧印加初期に小さ な放電量の発生数が比較的多い状態があり，次いでこ の発生数が減少し，放電量の大きい状㮩汇推移する。 その後再び小さな放䉓量の発生個数が増加する。この ように放電量の大きさについての分布が変化するのが 一般的である ${ }^{(4)}$ 。

〈3.2〉 放電劣化面の表面抵抗の变化 未劣化枳 リエチレンでは表面抵抗が $10^{15} \Omega$ 程度の徝を示すが， ボイド放電によって数分間㸓化させた後では $10^{21} \Omega$ 程 度に低下し，ほぼ 4 けた程度の減少怔見られる。これ は試料表面が酸化さ机ること，放笔生成物が表面にた い積すること，および放電によってボイド中に沓分が 発生することなどの專実加ら推定されることであり， 田中氏ら ${ }^{(8)}$ も放電停止数分後の試料で 3 けた程度の低 下を指摘している。しかし放電劣化された試料も，放電 停止後数時問経過すると，未劣化試料の捠抗値にまで 回復する ${ }^{(12)}$ 乙とを考慮すると，放謷中における壁面 抵抗值は，ここで测定された放筺停止後の測定值より あ更㖧下していると推定される。

〈3.3〉 放電発生場所の移動 集中法に抢いては 棒電極，または針電極から絶縁物に向けて円すい状に 定常的任広がる放電各継続するが，ボイド放雪では印 加電圧を一定に保った状態であってい第 6 図に示すよ うに変化する。すな⿰力口，䉓压を印加してからの時間 経過往つれて，(a)ボイド中心部全面（b)ボイド周 辺と中心の一部，拈よび（c）ボイド周辺と中心部が 弱く放電する傾向を示し，湿著な経時变化特性をむ $つ^{(4)(9)}$ 。その後，ボイド周辺の放電老主とする状態が 長時間持続することが多く, そ机兵, 長時間少化破 塤はその 90\% がボイド端で発生する。 


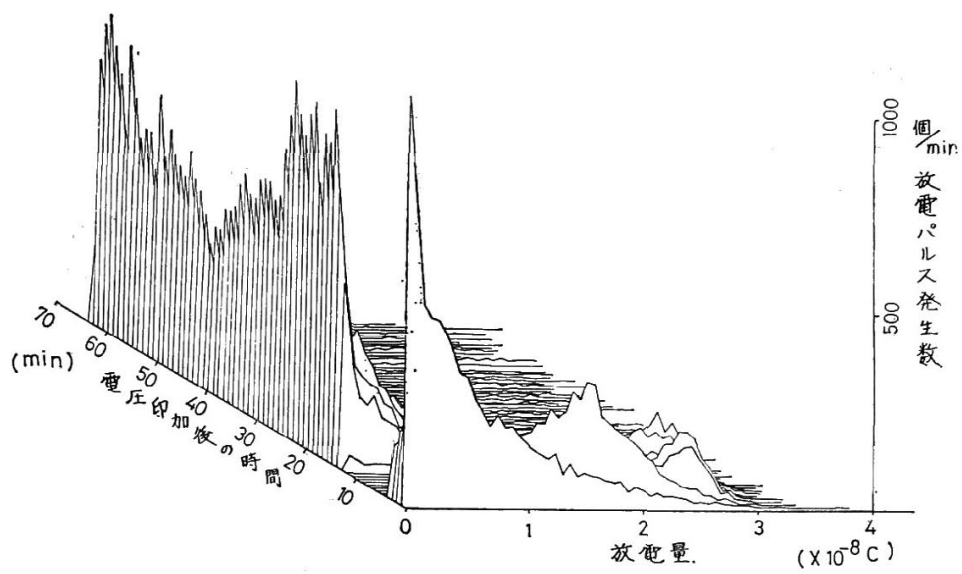

第 5 図 放電電荷分布の経時変化

Fig. 5. Time dependency of discharge magnitude distribution.

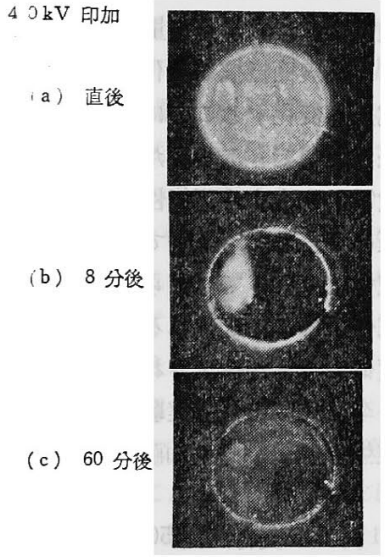

第 6 図 ボイド放電発光の経時変化

Fig. 6. The time dependence of luminouse discharging patterns.

\section{4. 実験結果と分圧電圧との対応}

本章では実験結果を用い，放電発光による放電発生 場所の変化㧍よび放電分布の経時変化を，ボイド内表 面抵抗一分圧電圧との関連に志いて述べる。おお，放 電分布はボイド内の気体成分が少化に伴い変化すると とにも依存するととが明らかになっているので(11)，と てでは放電発生場所との刘応について主に述べる。

〈4-1〉 未劣化状態（電圧印加直後） 電生印加直 徭の放電発光は第 6 図(a)に見ら机るように，ボイド 全面にわたっており，局部的に集中する放電は見られ ない。これは $R_{3}, R_{5}$ と屯にまだ少化によって低下す るに至らず，両者とむ $10^{10} \Omega$ 以上であり，分圧電圧
は $V_{\theta 2}, V_{\theta 5}$ が大きく，印加電圧の大部分は $g_{2}, g_{5}$ に 分圧されているとみら机る。すなわち，このことはボ イド全面にわたって放電が発生することに対応する。 第 5 図の放電分布では $10^{-8} \mathrm{C}$ 以下の放電パルス発生 数が多く，ての大部分はボイド中 (等価回路における $g_{2}$ で示される部分) で発生する放電パルスを示してい ると考えられる。 $C_{2}=28 \mathrm{pF}$ およびボイドの放電開始 電圧が $2.7 \mathrm{kV}$ (rms) 程度であるととから, との開始 電压で $C_{2}$ で示される領域が充電され，これが同時に 放電した場合の放電電荷の大きさは $10^{-7} \mathrm{C}$ となる。 この電荷の大きさは放電分布で測定される放電の大き さより 1 けた程度大きい。このてとから，ボイド中で 発生する放電はボイド全面が同時に放電するととはな 々，小さな領域が多数放電している状態と考えられ る。放電量の大きさから 1 個の放電パルスの放電領域 は $3 \mathrm{~mm}^{2}$ 程度となり，〈2.3〉節で $C_{5}$ 在仮定する場合 に用いた放電面積と対応する。

\section{$\langle 4 \cdot 2\rangle$ 過渡的劣化の進展（電圧印加数分～10 数分} 間）前章未劣化状態を経過し，劣化が進展するに つれ，放電発生場所はボイド周辺に一様あるいは周辺 の一部に集中する。との状態は分圧電圧特性で $V_{\theta 2}$ が 低い領域を示し，その範囲は $R_{3}<10^{8}, R_{5}<10^{9} \Omega$ で ある。一方，ボイド端の放電の発生，すなわち $V_{05}$ が 高い範囲は $R_{3}<10^{8} \Omega$ の場合 $R_{5}>10^{7} \Omega$ となる。従 って中心部で放電せず，周囲で放電する領域では，乙 の両者が両立する $R_{3}<10^{8}, 10^{7}<R_{5}<10^{9} \Omega$ の範囲に まで抵抗值が低下していることが推定される。放電発 光分布から中心の一部にも幾分放電発生が見られてい る。このことはボイド上下面の表面抵抗が全面にわた って均一に低下せず，局部的には $R_{3}$ が低下していな

昭 $50-8$ 
い領域が存在するためであるう。過隻的状態における 放電分布は，初期状態の放電の大きさの $2 \sim 3$ 倍の大 きさの放電の発生数が增大している。このととはボイ ド内気体成分の変化にも低存するが，放電発生場所か ら見るとボイド端で発生する放電に対応している。ボ イド端で起こる放電量が大きいことは田中氏らによっ ても報告されている。

〈4.3〉定常的劣化過程次第に劣化が進行し， ボイド端周辺始よびボイド全面にわたる放電が発生す 召状態に至り，ほぼ定常的劣化進行過程に入る。しか し，全面にわたる放電は電珐印加直後より弱い発光強 度を示す。この段階では $V_{q 2}$ 李幾分低下しているが, $V_{05}$ 亿本電压が分死され， $V_{q 2}, V_{05}$ の双方が放電する 状態であると考えられる。とのような分生特性を示す 抵抗値の範围は, $10^{6}<R_{3}<10^{8}$ および $10^{7}<R_{5}<10^{9} \Omega$ であるうと推定さ机る。従って，放電分布はボイド端 で大きな放電嘼の発生を示した前項の分布から，再び 放電譬の小さな発生ひん度の高い分布に変化する。

一万，等洒回路に上万分正電圧特性加ら， $V_{03}$ 忙 $R_{5}$ の低下によって上昇すると考えられ，乙の挋抗の範囲 が $R_{5}<10^{10} \Omega$ となれば $V_{03}$ による放電が発生する可 能性があると考えられる。前述のボイド中心やボイ ド端間の放電場所の变化があたらせる $R_{5}$ の籁囲は $10^{10} \Omega$ 则にすで低下していることが推定されてい る。促って $R_{5}<10^{10} \Omega$ の範国では， $V_{02}$ や $V_{95}$ によ

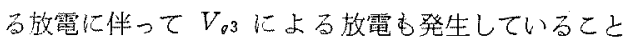
加推察される。しかし $V_{83}$ によって発生する放電は， 印扣電界方向に発生する放電と区別することが困蜼で あるため，実虽的に磪認することはできなかった。し かし，ここで示した等洒回路によって示さ机る分任暼 压による説明は今後に扔ける一つの指標となるである 5。

以上に示され九放電発生場所，放電分布之等洒回路 に上る分圧䉓王上の相豆関保は，ボィド内面の捏抗值 に上って示され石分圧電王の変化に対応させれれば説明 でるここが明らかとなった。良来加ら故電劣化表面 の抵抗值の減少は，放電停止後の测定值として多く報 苦さ机ている。その值は未劣化ポリエチレンて $10^{15} \Omega$ 程度の表面抵抗率加ら，劣化させることにより $10^{10}$ $10^{11} \Omega$ に低下寸る。しかし，上で述へててきた放電場所 に变化老屯たらす抵抗值は $10^{7} \sim 10^{9} \Omega$ ，表面抵抗率で
$10^{8} \sim 10^{10} \Omega$ を示し，放電中におけるボイド内面表面 插抗は，放䉓停止後の测定值より2けた程度更に低下 していると考えられる。

\section{5.むすび}

ボイド放電劣化模擬試験を行なっている場合，放電 の不安定性，放電場所の移動，放電の大きさや発生量 の変化，劣化面の表面抵抗の低下などが見られる。乙 抽の相互関係は結びつけられていないため，新しい 等価回路を提案し，実倹結果之対応させた結果，以下 のここが明らかになった。

（1）提案した等亚回路は，ボイド中，ボイド端周 囲およびボイド上下面に放電ギャップをもち，ボィド 内周囲に表面抵抗之，放電電荷蓄皘容量索仮定した点 に特徽を有する新しい等価回路である。

（2）ボィドを有する試料で発生する放電の発生堨 所の变化，放電の大きさや発生量の経時变化は，放笔 によってボイド内表面抵抗が変化し，放管ギャップに 分压される電圧が变化することに対応する。

（3）従来は説明できなかったが，勖加笔任と直角 方向に向う放電が発生する可能性を，ボィド内面で分 圧される笔仕の大ささから説明できるようになった。

（4）放䉓少化によってあたらされるボイド内表面 抵抗は，放電停止後に测定される値よりも，放電中て は 2 けた程度低いことが推定される。

終わりに，卒丵研究として夷験执上び解析を手伝わ

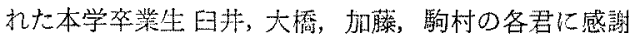
いたします。

(昭和 49 年 11 月 5 日受付, 同 50 年 5 月 22 日票受付)

\section{文献}

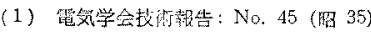

(2) 同上: No. 74 (䀡 41)

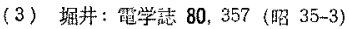

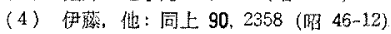

(5) S. Whitehead: Dielectric Breakdown of Solid (1951)

(6) F.H. Kreuger: Discharge Detection in High Voltage Equipment

(7) 塄, 化: 電学新 82,796 (目 37-5)

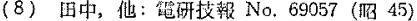

(9) 田中, 他: 同上 No. 70037 (m 45)

(10) 池四，他：同上 No. 73085 (保 49)

(11) 伊藤, 他：䉓気学会部文表 93-A, 115 (圈 48-3)

(12) 湖子; 算学茫 82, 592 (昭 37-4)

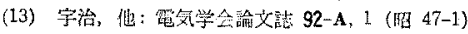

